\title{
A MONTESSORI-KONDUKTÍV NEVELÉSI GYAKORLAT PEDAGÓGIAI KÍSÉRLETE 2000-2003
}

\section{Szerző:}

Czigléné Farkas Katalin

Semmelweis Egyetem (Magyarország)

Szerző e-mail címe:

cziglene_farkas.katalin_maria@semmelweisuniv.hu

\section{Lektorok:}

\author{
Feketéné Dr. Szabó Éva \\ Semmelweis Egyetem (Magyarország) \\ Frank Tamás \\ Semmelweis Egyetem (Magyarország)
}

Czigléné Farkas Katalin (2018): A Montessori-konduktív nevelési gyakorlat pedagógiai kísérlete 2000-2003. Különleges Bánásmód, IV. évf. 2018/3. szám, 11-23. DOI 10.18458/KB.2018.3.11

\begin{abstract}
Absztrakt
Montessori pedagógiáját a kutatók nevezik fejlesztö vagy fejlödéspedagógiának. Magyarországon az utóbbi évtizedben a pedagógiai gyakorlatban fejlesztő pedagógiaként jelenítik meg. Mária Montessori módszerét fejlesztö pedagógiai módszernek tekinthetjük, mert sajátos nevelési szükségletü gyermekek fejlesztésére is alkalmas. Pedagógiai munkáját értelmi fogyatékos gyermekek körében kezdte el. A konduktív módszer a fejlesztés speciális komplex pedagógia módszerének tekinthetö, mert a tervezésben és a megvalósitásban sajátos nevelési szükségletet és a speciális nevelési igényeket veszi figyelembe. A Montessori fejlesztés a konduktív nevelés gyakorlatában nem fordult elö. A kutatással a Montessori módszer alkalmazását szélesíteni kívántuk a gyógy-és fejlesztö pedagógia gyakorlatában. Igazolni kívántuk a két orvos-pedagógus holisztikus szemléletéböl adódó hasonlóságot és különbséget. Petö holisztikus szemléletével magyarázható, hogy az érzékelés, észlelés, beszéd, mozgás és kommunikáció zavarát okozó állapot befolyásolását nem a különbözö helyen és időben dolgozó szakemberekre bizta. A Montessori konduktiv nevelési gyakorlatot 2000-2003, 2007-2008 tanévben kísérleti céllal vezettük be a konduktor hallgatók föiskolai képzésével összhangban. A program kidolgozásának a célja volt, hogy a két módszer elemeinek alkalmazását, összehangolt müködését a gyakorlatban igazoljuk.
\end{abstract}

Kulcsszavak: konduktív nevelés, Montessori pedagógia, pedagógiai kísérlet

Diszciplina: konduktív pedagógia, pedagógia

\section{Abstract}

The researchers call Montessori's pedagogy developer or development pedagogy. In the past decade, in Hungary, it appeared as development pedagogy in the pedagogical practice. The conductive education is a special, complex pedagogical method [6], because it takes into consideration special educational needs in planning and implementation. We can view Mária Montessori's method as a development pedagogical method, because it's suitable for children with special educational needs. Her pedagogical work began with children with intellectual disabilities. The Montessori development method has not yet occurred in conductive education. With our research we wanted to broaden the use of the Montessori method in the practice of special education and development pedagogy. We wanted to confirm the similarity and difference of the holistic approach of the two doctor-pedagogues. It's expicibale with Petö's holistic approach, why didn't entrust the development of perception, speech, motion, and communication difficulties to people working in different places and time. We intruduced the Montessori conductive educational 
practice experimentally in the semesters of 2000-2003 and 2007-2008, in accordance with the student's college education. The purpose of the program was to demonstrate the practical application of the elements of the two methods and their coordinated operation.

Keywords: conductive education, Montessori pedagogy, pedagogical experiment

Disciplines: conductive education, pedagogy

A Pető Intézet iskolai tagozatán az 1999/2000. tanévben valósult meg az az elképzelés, hogy a Nevelés- és Társadalomtudományi Tanszék kezdeményezésére a Konduktív Tanszékkel együttmüködve nevelési gyakorlat keretében Montessori foglalkozásokat szervezzünk. Korábban nem volt ilyen komplex pedagógiai kezdeményezés, csak Montessori-eszközök elemei voltak fellelhetőek a konduktív foglalkozásokon, ezért vizsgálatunk exploratív vizsgálatnak tekinthető.

A játékos tevékenység minden formáját alkalmazták a konduktív csoportokban: manipulációs, mozgásos, konstrukciós, szabály, didaktikai és szerepjátékok. 1995 őszén Dr. Bíró Katalin főiskolai tanár kezdeményezésére a harmadéves konduktor-tanítók képzésébe beépítették az úgynevezett komplex nevelési gyakorlatot. E képzési forma bevezetésének célja az volt, hogy a hallgatók megtanulják az iskolai ismeretszerzést, személyiség- és mozgásfejlesztést komplex módon, játékosan, nevelési gyakorlat keretében. Ezeket az ún. játékfoglalkozásokat a mozgássérült iskolások napirendjéhez igazítva egyéni járásfeladatokkal összekötve szervezték meg. Így a játék összefonódott a mozgásfejlesztéssel, és a kivitelezést nem direkt módon, hanem a játék keretein belül valósították meg. A tanult mozgásformákat észrevétlenül hajtották végre a játékos szituációkban és a szerepek megformálása közben.

A személyiségfejlesztő játékok sorában a játékeszközök között található volt néhány Montessori játék is. Ezek használata azonban esetleges volt. Az egyes eszközök hierarchikus egymásra épülésének lehetőségét nem használták ki. A gyöngyök, érzékelésfejlesztő eszközök, kockák, hordók használatának célja a gyermek mozgásállapotának megfelelő segítségadás, megadott szempont szerinti spontán tevékenység volt.

\section{A konduktív nevelés}

A kutatási stratégia kivitelezéséhez, az empirikus kutatás egyik helyszínének a diszfunkciós iskolás gyermekeket oktató-nevelö iskolai gyakorlóterületet választottuk. Ahhoz, hogy a választás helyességét a téma szempontjából igazoluk, szükséges, hogy a konduktív nevelés célját, speciális eszközeit és módszereit összefoglaljuk, valamint a Pető és a Montessori alapelveket vázlatosan összehasonlítsuk a konduktív nevelésre vonatkozó speciális fogalmak értelmezésével a Dr. Hári Mária, Kozma Ildikó, Horváth Júlia, Kőkuti Mária (1999) A konduktív pedagógiai rendszer hatékony müködésének alapelvei és gyakorlata címü kiadványban leírtak alapján.

Az intenció. Jelentése: Az akarás energiája, erőfeszítése mellett jelentkezik egy belső ritmus, amely a cselekvés belső képe, tervezete. Az intencióhoz kell kapcsolódnia mindazon szervezésnek, amely egy mozgást létrehoz, vagy megszüntet, a felesleges mozgást elnyomja. Ez a szervezés a cselekvés fontos pozitív faktora anélkül, hogy tudatossá válna. Az intenció és megvalósítása azt az egységét képezi, amit akarunk tanítani. Ha az ember megtanult egy cselekvést, azaz megtanulta, hogyan tud elérni egy kitüzött célt, nem csupán a látható cselekvéssort tanulja meg, hanem a helyes intenciót is. A belső újraszerveződés egyben az intenció újraszerveződése is. Ha elemezzük magát a cselekvés jelenségét, azt találjuk, hogy a cselekvés akkor lesz ökonomikus, harmonikus és hatékony, ha már ortofunkciósan megszerveződött.

Az ortofunkció kialakitása. Az ortofunkció olyan pontosan szervezett müködés, amelynek lényeges része az észlelés. Az ember úgy hajtja végre mozdulatait, hogy azok megfeleljenek az intenció által előzőleg alkotott belső képnek. Nevelés segítségével a koordináció előzetes 
kialakítása, majd annak szisztematikus alkalmazása képezi, hogy ami kezdetben kognitív volt, az a megszervezésében és a lefolyásában mindinkább automatikussá váljék.

Az aktivitás létrehozása. A konduktív pedagógia aktivitásnak tekinti az aktív részvételt, a motiváltságot, az érdeklődést is. „Aki akar, aktív, és célt akar elérni." A célirányos tevékenység képességének kialakítására irányulás a konduktori magatartás alapkérdése: elérni, hogy a gyermekek, felnőttek akarják valamely cél megvalósítását, mert az indíték, az intencionális aspektus fontos. „A célnak érzelmi jellege is van, és összetettebb is, mint egy absztrakt mozgásprobléma” (Hári és tsai, 1999). Minden probléma számára értelmes, érdekes cél kell, hogy legyen, ami vagy valós, vagy legalább szimulálja a valós helyzetet. Ezért a problémának olyannak kell lennie, amely az illető számára mint cél érdekes, jelentős, szükséges, egyszóval vonzó. Az egyén nem a kész probléma megoldását kapja, hanem a konduktor rávezeti a saját megoldás megtalálására. A konduktív nevelés eredményessége elsősorban az aktivitást létrehozó pedagógiai munkán múlik, nem speciális „módszerek”, „technikák” alkalmazásán, függetlenül attól, hogy ilyenek is vannak, és ezekre is szükség van.

A komplex személyiségfejlesztés. A konduktív pedagógia által kitüzött célok nem speciálisak, nem különböznek az egészséges kortársakétól. Csupán a követelmények kielégítéséhez vezető adaptív-tanulási folyamat során meghatározott célok tekinthetők speciálisnak abban az értelemben, hogy a problémamentesen müködő személyiség esetében a célok spontán módon elérhetők. A koordinált müködés alapja az idegrendszer különböző területeinek összmüködése, ami nem valósulhat meg külön-külön gyakorlásokkal. A csoportos tanulási forma a diszfunkciósok fejlődésében éppen olyan szükséges tényező, mint az egészségesek nevelésében. A konduktoroknak a gyermekek, a felnőttek egész személyiségét érintő általános befolyása a csoporton keresztül érvényesül igazán.

A kondukció. A kondukció a tanító funkciója, az ő szisztematikus megnyilvánulása, amit hozzáad a tanítványa önálló, egyedi funkciójához abból a célból, hogy az idegrendszer sérült vagy hiányos működése következtében szétesett funkcióknak az összerendezése megszülessen. A helyes kondukció ahhoz segít, hogy a tanulónak legyen célja, bizalmat ad és biztonságot, valamint minden lehetséges eszközzel biztosítja az aktivitást és az önálló célelérést. Ez az emberi méltóság és a személyes szabadság fontos szemlélete.

A konduktív megfigyelés sajátossága, hogy a pedagógiai gyakorlat szerves része. A megfigyelés a facilitációs lehetőségekkel együtt a kondukció lényegi eleme, a fejlesztő munka elengedhetetlen része, a nevelési gyakorlatból kiszakítva elvesztené a célját. A folyamatos megfigyelés lehetőséget biztosít az eredmények felismerése és a teljesítmények leírása mellett a továbblépések lehetőségeinek feltárására, az új eljárások kipróbálására.

A konduktív megfigyelésre jellemző a globális szemlélet. Átfogó jelleggel vizsgáljuk az egész személyiséget, valamint a fejlesztési folyamat egészét. A feladatszituációban történő megfigyelés alkalmat ad arra, hogy megtapasztalják a diszfunkciós adaptációs képességét. Feladatszituáció lehet a különböző feladatsorok megoldása, a konduktor direkt utasításainak teljesítése az óvodai vagy iskolai foglalkozásokon. A konduktív megfigyelést értelmezve beszélhetünk operatív, progresszív és komparatív jellegről. Az operatív megfigyelés alkalmával a probléma megállapítása és a célkitüzés után a feladatokat határozzák meg, kidolgozzák annak megoldási módját, ezzel egy időben körülhatárolják a megfigyelendö jelenségek köret.

Pedagógiai értelemben vett segítség (rávezetés) azoknak a módszereknek, fogásoknak az alkalmazása, amelyek révén a gyermekek, felnőttek számára a cél elérhetővé válik. Ha a mozgássérült akar, de nem kap segítséget, vagy nem jó időben kapja, akkor kóros mozgás jöhet létre, ami visszahat az akaratra, és gátolja azt. Az akarat és érvényesítésének helyes módja, az ehhez adott segítség a facilitáció, amelynek leglényegesebb sajátossága, hogy beépül, interiorizálódik a diszfunkciós személyiségébe.

A ritmikus intendálás a feladatok végrehajtásakor a résztvevők egyes szám első személyben hangosan kimondott szándéka (a cselekvés terve, mit és hogyan fognak csinálni) azaz az intenciójuk verbalizálása, majd a szándékuk szerinti cselekvés végrehajtása az erre szánt időtartam alatt, amelyet számolással, dallal, verssel jeleznek. Az intenció verbalizálásának különböző formái 
lehetségesek. Az intonáció (hangsúly, hanghordozás, hanglejtés) ugyancsak a ritmikus intendálás fontos része.

A komplex program. Egy adott csoport éves munkaterve tartalmazza a gyermekek és a szülök fontosabb adatait, a napirendet, órarendet, feladatsorokat (fekvő, állás-járás, manipuláció, erősítő feladatok, tartásjavító feladatokat stb.), egyéni feladatokat, valamint az egyéni éves célkitüzéseket. A munka minősége lemérhető az egyéni célok elérésének tükrében. A program sajátossága, hogy multidiszciplináris és egyidejü egységet képző diszciplinákból tevődik össze, metodikai egységbe foglalja a beszédtanítást, értelmi, érzelmi, akarati fejlesztést, az önellátási szokások, a manipulációs készség és helyváltoztatás kialakítását.

Tartalmát a biológiai és társadalmi követelmények rendszere határozza meg. Ez a követelményrendszer tükrözödik a napirendben, így annak minden egyes mozzanata a program része. A központi idegrendszer összehangolt müködéséhez az egyes részképességeket egységes rendszerben kell fejleszteni, amelyet a tudatosan tervezett komplex program biztosít.

A diszfunkciósok a konduktív nevelés folyamatában személyre szabott céllal, életkori sajátosságaiknak és mozgásfejlettségüknek megfelelő programokkal csoport-, illetve osztálykeretek között interaktívan vesznek részt.

A napirend rugalmas, életkornak és tünettípusnak megfelelő szervezeti keret, amely koherens és folyamatos. Ami megkülönbözteti az általános jelentéstől, az a szerep, amelyet folyamatosságával és koherenciájával betölt a sérültek életében. A program a személy és nem a funkció számára készül; mégpedig egyénenként a legmegfelelőbben kiválasztott célok elérése érdekében.

A napirendben egymással összefüggő feladatsorok épülnek egymásra, fokozati szempontból előkészítik, kiegészítik a foglalkozásokat. Időtartamuk a csoport jellege és teherbíró képessége szerint változó. A részekből álló teljes napi program egy jól szerkesztett egészet alkot. Nagyon lényeges, hogy a részek csak akkor fognak funkcionálni, ha az egyén számára is van jelentőségük. A napirend megvalósítása folyamán motoros és kognitív tevékenységeket formálunk tevékenységek által.

A feladatsort alkotó feladatok nem egyszerü gyakorlatok, hanem biológiai értelemben vett célirányos, és szándékolt (intendált) tevékenységsorok komplex módon, kognitív elemekkel probléma-centrikusan és algoritmust alkotva (tünet-specifikusan) felépítve. A feladatsorok a követelmények rendszerét tartalmazzák.

A feladatsort tartalmazó feladatok megoldásának célja és egyben eredménye is az aktív magatartás, amelyhez kezdeményezés, cselekvés elhatározása, az akarás energiája, a cselekvés megkezdése, a cselekvés folyamatához illő izomtónus megválasztása, az ellentétes irányú mozgások beindulásának a megakadályozása és a legkülönbözőbb kóros mozgásformák szabályozása társul. A feladatsorok megoldása mindig frontális irányítással történik: a csoport tagjai együtt haladnak a feladatokkal. Ha a feladatok megoldása automatizálódik, ahhoz módosíthatjuk a környezeti feltételeket, csökkenthetjük a megoldáshoz adott facilitációt, új, esetleg bonyolultabb feladatokat határozhatnak meg, megváltoztathatják a kiindulási helyzetet, a megoldáshoz szükséges időt lerövidítve gyorsíthatják a ritmust, megváltoztathatják az intendálás módját. Ahhoz, hogy a helyzetés helyváltoztatás elsajátított módjai, a tanított és tanult ismeretek készséggé, képességgé váljanak, szükség van arra, hogy a mindennapi élet összes tevékenysége során felhasználásra kerüljenek (Hári és tsai 1999; Horváth, D. és Salga, J. 2005).

\section{Montessori módszer}

A Montessori alapelvek megértésének feltétele a sajátos Montessori fogalmak megismerése. Montessori körülbelül 150 új fogalmat vezetett be koncepciójának kidolgozása alkalmával. Alább, a konduktív pedagógiával rokonítható, párhuzamba állítható fogalmakat mutatjuk be.

Abszorbeáló tudat. A kisgyermekekben található egy ösztönös szellem, amelynek teremtő ereje van. Ezt abszorbeáló léleknek nevezte (felszívó értelemnek is szokták nevezni). Nem akarati 
erőfeszítésekkel épít, hanem „belső szenzibilitás” bevezetésével, úgynevezett szenzibilis periódusban nyilvánul meg. A gyermeknek az a képessége, amely segítségével a kisgyermek akaratlanul is tanul környezetétől (Bíróné Balog, Bordács és Németh, 1998).

Figyelem polarizációja. A gyermek figyelemtartása, reakciója bizonyos külső ingerekre. Elvezet a koncentrációhoz, vagyis a gyermekek a munkát összeszedetten végzik, nyugodtan, belsőleg megerősödötten. A koncentráció útján jut el a normalizációhoz, az élet rendjéhez, a célirányos tevékenységhez (Bíróné Balog, Bordács és Németh, 1998).

A gyermek szabadsága. A szabadságot fel kell építeni. A szabadság gondolatának figyelembevétele nélkül nem lehet helyesen értelmezni ezt a módszert. A szabadság lényegéről, a nevelés és a szabadság összefüggéséröl szóló felfogását Montessori nem írje le résztematikusan, konkrét dolgoknál részletezi a problémát. Szintézise az alábbiakban foglalható össze. A szabadság jelensége: nem lehetünk szabadok, ha nem vagyunk függetlenek. A függetlenség, a szabadság és az emberi méltóság belső kapcsolata az ember elidegeníthetetlen joga. A szabadságot akkor éri el a gyermek, ha saját belső törvénye szerint fejlődési igényeinek megfelelően bontakozik ki. A gyermeknél az emberi méltóság tudata a függetlenség tapasztalatából ered. Aki ma az iskolai szabadságról beszél, annak a szabadságot lehetővé tevő környezetet kell előkészíteni és ezt felkínálnia. Tehát Montessorinál a szabadság és az elökészített környezet kölcsönösen feltételezi egymást (Pukánszky és Németh, 1996; Bíróné Balog, Bordács és Németh, 1998).

Mivel az ember szociális lény, ezért a szabadság is csak szociális keretek között létezhet, hiszen az ember embertárssá válásával valósul meg. Ezért Montessori a szabadságot a szervezett társadalom szükséges alapjának tekinti. A szabadság immanens normáin a helyes szabadságfelhasználás kritériumait értette. A gyermekeknek meg kell adni a szabadságot, hogy tevékenységeit spontán módon válassza meg, és kövesse belső ösztöneit. A normák világszemléleti rögzítéseire három válasz létezik: önmagunk lenni, a dolgok hangját hallani és szeretni. A világhorizontról, az értékek horizontjáról meggyőződése a keresztény hitben rejlik. Az önmagunk mesterének lenni nézőpontját a hitben való megerösödésben találja. A dolgok hangja kijelentés mögött pedig a „természet hívásában az isten hívását lehet felismerni”. A szeretet nála „,isteni szeretetben” ölt testet. A munka, a tevékenység megismétlésének jelensége minden gyermeknél megtalálható: újra és újra megismétli a gyakorlatot, majd minden külső segítség nélkül abbahagyja. Ha már uralkodik a tevékenység különböző mozdulatain, alábbhagy az igény, hogy gyakorolja őket.

A tevékenység eszköz és a tanuló kontextusában megismeri, gyakorolja, tanulja az eszközt. A gyermek számára elökészitett környezet minden tárgya úgy legyen elrendezve, hogy ösztönző legyen, külső célokat ajánljon. A gyermekeket arra szólítsa fel, hogy cselekedeteit érdeklődésből kezdje el, és a kezdeti tevékenységet követi majd az ismétlés (Mészáros és tsai, 2003). A környezetet hagyjuk, hogy vezesse a gyermeket a munkában. Minden tárgynak, amely ezt a környezetet alkotja van egy közös tulajdonsága, a hiba kontrollálásának lehetősége. A mai pedagógia szakkifejezése, az önellenőrzés képességének a fejlesztése.

A hagyományos iskolában a gyerekek a tanulásban elfáradnak, ezért megpróbálnak kevesebbet tanulni. A tanárnak külső fegyelmi eszközökkel kell ösztönözni a teljesítményt. A montessoris gyermekek érdeklődéssel, akarattal és örömmel tanulnak. Nem fáradtak (Huber és Kaul, 1993).

„Montessori gyermekeinek” érdeklődése és öröme a mai pedagógiai értelmezés szerint belső motivációt jelent. A belső motiváció a megismerő tevékenység egyik energiaforrása, intrinzik motivációnak is nevezik. A szekunder (extrenzik) motiváció a tevékenység tárgyától rendszerint független külső indíték. Ilyen a jutalom és a dicséret. Kim Rita tanulmányában (1998) a Montessori szemléletű pedagógia és az intrinzik motiváció kapcsolatáról a következőket fogalmazta meg: „Az iskolai tanulás motiválásában a belső motiváció és az autonóm viselkedés befolyásolása döntő jelentőségü. Az iskolai osztályok olyan jellegü megszervezésére van szükség, ami a belső motivációt lehetővé teszi” (Kim, 1998). A gyakorlati megvalósítása Maria Montessori pedagógiájában figyelhető meg. A mai Montessori iskolák szervezeti felépítésében, tanulási környezetében, tanítási-tanulási módszereiben, eszközökben, tananyag elrendezésében, pedagógus szerepében nyomon kövezhető (Kim, 2008). Az elökészített környezetnek tartalmaznia kell az önnevelés eszközeit. Csak hosszú kísérletezés alapján alakulnak ki az eszközök, amelyek fontosak a 
pszichikai fejlődésben”. Pedagógiájának egyik sajátossága a tematikusan felépített eszközrendszer.

A cselekedetre motiváló környezet előkészítése a Montessori nevelés gyakorlati alapja.

A megfigyelés. Figyelni nem egyszerü. Előkészítést igényel. A megfigyelés célja, hogy lássuk, mit csinál a gyermek, jelenlétünktől függetlenül. Szükséges tehát a tudatos mozdulatlanság gyakorlata, az önuralom, a türelem (Bíróné Balog, Bordács és Németh, 1998).

Az eszközrendszer ismerete: A Montessori eszközrendszert nem elég megismernie, hosszú ideig kell gyakorolnia, hogy tudja interpretálni. Az aktivitás radikális eltolása. Az aktivitás a hagyományos oktatásban a tanárnőé, a Montessori módszer alkalmazásával a gyermeké lesz.

A tárgyak nem a pedagógus szemléltető eszközei, aki ezek segítségével szemléltet a hagyományos oktatásban. A gyermek fejlesztésére szolgálnak, aki kiválasztja őket, elveszi, használja érdeklődési ösztönzése szerint. Így lesz a tárgyakból fejlödési eszközrendszer. A pedagógus a katalizátor szerepét tölti be az eszköz és a tanuló kapcsolatában (Bíróné Balog, Bordács és Németh, 1998).

Maria Montessori az egyes eszközökkel való tevékenységet, a munka bevezetését leckének nevezte. A leckék általában akkor következtek, amikor a gyerek már tapasztalatokat szerzett az eszközzel kapcsolatban, vagy különleges érdeklődést mutatott iránta. Minden lecke alapja a pontosság és az áttekinthetőség volt. Fontos volt, hogy a gyerek hozza el az eszközt a szabad polcról, hogy megismerhesse a helyét, és használat után visszavihesse oda

Kidolgozta a három lépcsőfokú lecke lépéseit:

1. lépcsőfok: A nevelö létrehozza a kapcsolatot a tárgy és neve (illetve a tulajdonság és a megjelölés) között úgy, hogy rámutat a tárgyra, és közben lassan, érthetően mondja a nevét. Így a tárgyak, fogalmak és megnevezések szorosan összekapcsolódnak. „Ez....” megnevezés a nevelő által.

2. lépcsőfok: A megjegyzés, rögzítés fázisa. Ez a fázis minden gyermeknél különbözö időtartamot vesz igénybe. A nevelő megnézi a fogalmat, és megbízásokat ad a gyereknek vele kapcsolatban. A megbízások gyakori váltakozásával a gyerek megtanulja elhelyezni a fogalmakat, és nem veszíti el érdeklődését. Az ismétlések a gyerek számára sokrétüek és érdekesek. Figyelembe veszik a gyerek erős mozgási kényszerét is. „Add ide, hozd, tedd ide a ....." - felismerés a gyerek által.

3. lépcsőfok: A nevelő mutat egy tárgyat, és rákérdez a nevére. Ezzel a passzív szókincs átalakul aktívvá. A gyerek most már a tárgyat és a nevét is birtokolja. A 3. fok egyúttal a 2. fok kontrollja is. „Mi ez?” vagy „Milyen ez?” - Megnevezés a gyerek által (Huber \& Kaul, 1993). Az eszköz által nyert tapasztalatokat a gyerek kipróbálta, és felhasználta saját környezetében. „Normalizálja” (Montessori kifejezés) magát azáltal, hogy szellemi-lelki erőit koncentrálja, rendezi és kibontakoztatja. Mindezek eredményeként személyi és tárgyi környezetéhez füződő viszonya elmélyült.

\section{A kísérlet}

A kísérlet célja volt a mozgássérült csoport helyzetének elemzése, valamint a kísérlet során megállapításokat tettünk a független változó (Montessori módszer) hatására okozta változásokra. Típusa szerint kéttényezős, mivel két olyan független változóval dolgoztunk, amelyek mindegyike önmagában is hatékony. Feltételezhető volt, hogy hatékonyságuk nem függött a másik független változótól (Csíkos, 2012). Az egyik független változó a konduktív nevelés módszere, a másik a Montessori módszer. A két független változó hatására a függő változóban, a mozgássérült tanulók képességeinek fejlesztésére hatást gyakorolt. 


\section{Hipotézisek}

1. Hipotézis: A fejlesztő eszközökkel folytatott tevékenység a mozgássérült tanulók képességeinek fejlesztését segítik.

1.1. Az időbeli szabadság az egyéni tempót és az optimális tanulói tevékenységet fejleszti.

1.2. Mozgásszabadság lehetőséget nyújt a munkaeszköz választásában és az eszközök elpakolásában.

1.3. Az eszköz kiválasztása a tanuló önálló döntésének szabad gyakorlását segíti.

2. Hipotézis: A nevelési gyakorlaton a konduktív nevelés céljait a Montessori módszer alkalmazása segíti.

3. Hipotézis: A Montessori eszközzel történő tanulói tevékenység alkalmával a hibák kontrollálása, javítása, az önellenőrzés biztosítása megvalósul.

4. Hipotézis: Új eszköz hallgatói bemutatása segíti a három fokozatú lecke tanulását, megismerést, felismerést, felidézést.

5. Hipotézis: A szabad tanulás önállóan és tanulói együttmüködésben történő megvalósulása történik.

\section{Minta}

A kutatásban résztvevők köre a következőképpen alakult: 7-8 éves 13 fö, 9-10 éves 11 fö. Húsz hallgató és 3 konduktor vett részt a kutatásban.

\section{Módszer}

A Montessori-Konduktív Nevelési Gyakorlat tervezéséhez, szervezéséhez és irányításához kapcsolódó intézményi dokumentumokat vizsgáltára került sor. A 2000-2003-ig tartó időszakban egycsoportos (önkontrollos) kísérlet valósult meg (Falus, 1993).

A konduktor hallgatók voltak a megfigyelök, akik a kötetlen megfigyelés módszerét alkalmazták. Folyamatosan részt vettek a konduktív képzési követelményeknek megfelelöen a gyermekcsoport életében és ismerték a csoport tevékenységét. A konduktor hallgatók megfigyelö tevékenységének időkorlátai a képzési követelményben meghatározott 60 perc volt. Ezáltal speciális pedagógiai helyzetben voltak, mert ismerték a gyermekeket, résztvevő megfigyelést tudtak végezni a csoportban.

A megfigyelések rögzítésére naplót, feljegyzéseket készítettek. A napló vezetését a résztvevő megfigyelés legalkalmasabb feldolgozó technikájának tartottam.

A kutatás módszere az írásbeli kikérdezés, mérőeszköze a kérdőív. A kérdőíves megfigyelést a hallgatói csoport végezte egyéni és strukturált megfigyeléssel.

A kérdöíves méréssel a kutatás célja volt az információgyüjtés, a következtetések levonása, az előkutatás eredményeinek alátámasztása mérési becsült adatokkal a hipotézisben megfogalmazott alapvetések igazolására. A Montessori-konduktív gyakorlaton a tanulói tevékenység megnyilvánulásait a föiskolai hallgatók az ún. hallgatói kérdőívben rögzítették. A kérdőív kérdéseinek megszerkesztésénél „Általános szempontsor a konduktív nevelésben résztvevő mozgássérült gyermekek fejlődésének regisztrálására" címü kiadvány szempontsorait vettem figyelembe. A kérdések tartalmi felépítésében egyrészt a mozgássérült tanulók sérülésspecifikus tulajdonságait, valamint a hipotézisemben felsorolt Montessori alapelveket vettem figyelembe. Mivel a kérdőív nem volt „kipróbálva”, ezért az összeállítása után megbízhatósági mérést végeztünk konduktív és a kontroll csoportban. Mérés eredményei biztosították az alkalmazhatóságot.

A kontrollcsoport megválasztása nem volt könnyü feladat, mivel a korosztály és sérülés súlyosságából adódó heterogenitás akadályozta a mintavétel homogenitását. A kontroll csoport életkora 9-10, míg a Montessori csoporté 10-13 év. A közös életkori szakasz a 10. életév volt. A 
megbízhatóság érdekében a tanulónkként elkészített szakértői vélemény jelentette a kiindulópontot. A fejlődés és fejlesztés homogenitása indokolta az egy csoportba tartozást.

A módszer és eszközválasztást a kontroll csoport esetében a „szabad játék”, a Montessori csoportnál pedig a Montessori fejlesztő tevékenységet jelentette. A szabad játék a kontrollcsoportban a szobában megtalálható játékokat és Montessori eszközöket jelentette (baba, játékautó, építőkocka, társasjáték és Montessori eszközök). A foglalkozás spontán módon kezdődött. A játékokat elővették, és játszottak velük (tologatták a kis autót, babáztak, társasjátékkal játszottak). A Montessori eszközök fejlesztő- és „mérőeszközként” is szerepeltek. Fejlesztő eszköz volt, mert valamilyen részképességet fejlesztettek. Mérőeszköz volt, mert az eszközzel történő tevékenység során időt, a tanulói tevékenység módját adatként rögzítettük.

\section{Eljárás}

A Montessori csoportban a fejlesztő foglalkozás felépítése tervezett, strukturált volt.

A konduktivv kérdőivet a Pető Intézet óvodai és iskolai tagozatán dolgozó konduktorok töltötték ki. A kérdések arra irányultak, hogy a mozgássérült gyermekek tanórán kívüli tevékenységében alkalmazott pedagógiai módszerek milyen összefüggésben vannak a tanuló képességfejlesztésével. Van-e kapcsolódási pont a Montessori tevékenységekkel?

A Montessori-Konduktív nevelési gyakorlat tervezésekor a tematikusan felépített Montessori eszközök bevezetésére törekedtünk. A nevelési gyakorlat egyik célja volt a Montessori módszer és eszköz használatának és alkalmazásának megismerése, olyan pedagógiai környezet biztosítása, ami feltétele a módszer és eszköz ún. Montessori alkalmazásának. A pedagógiai környezetet a nyitott polcon elhelyezett eszközök jelentették, a csendgyakorlat, a beszélgetőkör és új eszköz megismerése, bemutatása.

A gyakorlat másik célja volt az eszközök fejlesztő hatásának megfigyelése. A gyermekek szempontjából a részcélokat az önállóság, az egymásra való odafigyelés, a képességfejlesztés, a szociális fejlődés, az érzékelésfejlesztés jelentették. Az általános részcélokat a hallgatók szempontjából is meghatároztuk. A gyermek megismerése, a gyermek és a hallgató közötti partneri kapcsolat elmélyítése, pedagógiai módszereik gazdagítása a mozgássérült gyermekek fejlesztésében.

A foglalkozás konduktív célkitüzését az általuk elkészített foglalkozási tervekben határozták meg a hallgatók. A konduktív célok megvalósítását összehangolták a Montessori eszköz és módszer alkalmazásával (pl.: önálló járás megtervezése tanulónkként a polchoz, ahol az eszköz volt megtalálható). A hallgatóknak egyrészt az önálló járást, közlekedést kellett egyénileg megtervezniük, másrészt az ülés, helykijelölés alkalmával a sérülésspecifikus állapotnak megfelelő egyéni feladatokat tervezni és elvégezni.

A gyakorlat megvalósításában mentorként vettek részt a Montessori óvodapedagógusok, tanítók és a Montessori Egyesület elnöke. A gyakorlat megkezdése előtt a hallgatók szakmai felkészítésének első lépcsőjét a szakirodalomban való tájékozódás, a második lépcsőt a Montessori intézményekben végzett hospitálások jelentették. A hospitálásokat a Csepeli Montessori és a Békásmegyeri Montessori óvodában végeztük. Az óvodai látogatás célja volt a pontos eszközhasználat, a pedagógus szerepének a megfigyelése, a csendgyakorlat és az új eszköz bemutatása. Látogatást tettünk a Batthyány Lajos Általános Iskola alsó tagozatos Montessori osztályában is. Az iskolai látogatás alkalmával azt figyelték meg, milyen módon lehet alkalmazni a Montessori eszközt a tantárgy és a tanórai rendszerben. A Montessori módszerek alkalmazásának lehetőségeit hogyan használták ki a Montessori többségi tanítók a tanórán. Az óvónők és a tanítók a Montessori szakképzést elvégezték, és több éves gyakorlattal rendelkeztek. A megfigyelések tapasztalatait feljegyzés formájában rögzítették a hallgatók.

A felkészítés befejező lépése volt, amikor a hallgatókkal megbeszéltük a foglalkozások megtervezésének lépéseit. A gyakorlat időkerete a főiskolai tanulmányi rendhez alkalmazkodva fél év volt, őszi félévvel kezdtük a programot. Tizennégy hét állt rendelkezésünkre, heti 2 alkalommal. 
A foglalkozások 60 percesek voltak, amit részletes elemzés, értékelés követett. Az őszi félév után terveztük a tavaszi félévet, vagyis a tanulók foglalkozása és a hallgatók felkészítése töretlenül ment tovább. A Montessori-konduktív nevelési gyakorlat három év alatt két konduktív hallgatói csoportot és két diszfunkciós gyermekcsoportot érintett. A gyakorlat megkezdése előtti félévben történt a hallgatók felkészítése. A gyakorlatok befejezése után pedig a hallgatók részéről az utógondozás. A megfigyelési naplók elkészítése, valamint szakdolgozatok készítése, Montessori záró foglalkozás vállalása.

A főiskolán bevált pedagógiai gyakorlat mintáját követve, két hallgató készült fel a foglalkozásokra. Mivel abban a csoportban zajlott a foglalkozás, ahol eleve folyamatos konduktív gyakorlatot végeztek a hallgatók, ezért a gyermekekre tervezett egyéni konduktív és Montessori célok, feladatok meghatározása nem jelentett nehézséget. Jól ismerték a gyermekeket. A gyakorlat tervezésének alapelve volt egy új eszköz bemutatása, megismerése, amit a hallgatók maguk készítettek el. Ezek az eszközök a Montessori és adaptált Montessori eszközök voltak (pl. gombolós keret). Az alapeszközöket tematikus rendben a Montessori Egyesület biztosította A hallgatók által készített eszközök arra a polcra kerültek, ahol az adott eszköznek helye volt (pl. gombolós keret a mindennapi élet tevékenységei eszközök között szerepelt, amit ma életvitelnek mondunk). Az eszköz megfelelő helyre kerülésének célja volt, hogy a gyermekek tudják eredeti helyükre visszatenni az eszközt a Montessori „rend” elvének megfelelően (Bíróné Balog, Bordács és Németh, 1998).

Az eszközök előkészítésének alapvető szempontja volt, hogy a célcsoportba milyen tanulók tartoznak. A célcsoport tanulásban akadályozott mozgássérült tanulók voltak. A 2000-2001 diszfunkciós gyermekcsoportban az életkor 9-10 év, a 2002-2003. gyermekcsoport 7-8 éves életkor volt.

A foglalkozások szakmai programjának előkészítésén kívül kidolgozásra került a Montessori gyakorlat hallgatókra vonatkozó képzési feladata és követelménye is, amelyek az alábbiakban összegezhetők:

1. A hallgató nyerjen betekintést a Montessori pedagógia elméletébe és gyakorlatába (elméleti előadás, óvodalátogatás).

2. A hallgatók készüljenek fel a Montessori-fejlesztő gyakorlat, ill. foglalkozások tervezésére, szervezésére, irányítására, a Montessori pedagógia és a konduktív pedagógiai ismeretek tudatos alkalmazására, a fejlesztő foglalkozások kivitelezésére.

3. A hallgató képes legyen a fejlesztés lehetőségeit megtalálni, kidolgozni az adott eszköztípus által. Feladatai:

- a mozgássérült gyermekek pszichomotoros, érzelmi és szociális fejlődésének pontos regisztrálása

- a mozgássérült gyermek adottságainak, fejlettségi szintjének, haladási tempójának folyamatos figyelembevétele

- a szabadság és az önállóság, a felfedezés élményeinek segítése

- a megismétlődő tapasztalás előkészítése a pedagógiai környezet kialakításával

- a manuális, finommotoros képességek fejlesztése

A konduktorral szemben támasztott követelmény volt:

- részvétel a foglalkozások tervezésében

- a hallgató folyamatos felkészítése a foglalkozásokhoz szükséges facilitációk tervezésében

A főiskolai-oktatóval szemben támasztott követelmények voltak:

- a hallgató folyamatos felkészítése a fejlesztő feladatok megválasztásában

- a tudatos alkalmazás és foglalkozáselemzés biztosítása

- a hallgatói teljesítmények értékelése, bejegyzése (aláírás) 
A hallgatói minősítés szempontjai:

- önértékelés a pedagógiai tudatosság, szakszerüség, tárgyilagosság és eredményesség alapján

- a helyettes tanító elemzési szempontjai alapján közös megbeszélés, bírálat

- a hallgató tevékenységének az oktató által történő értékelése

A hallgatóval szemben támasztott követelmény:

Véglegesített, teljes értékü, korrigált foglalkozási vázlattal történő felkészülés és egy adott foglalkozás levezetése, elemzése.

A hallgatóknak ismerni kellett:

- Néhány sajátos Montessori alapelvet a gyakorlatban való tájékozódásra

- Montessori nevelési koncepcióját

- A saját fejlődési fázisokat

- Az integrális fejlődési területeket

- A pedagógus megváltozott szerepét

- A gyermekekkel való kapcsolatot

Jártas legyen:

- Az eszközök funkcióinak ismeretében a gyerekek fejlesztésében

- Tanuljon megfigyelni, csendesnek és türelmesnek lenni

- Jártas legyen az ,aktív” feladatok közvetítésében a gyerek és az eszköz között

- Ismerje meg a Montessori eszközöket

- Sajátítsa el a technikákat, az eszközök használatát

- Tapasztalatot szerezzen az alapelvek elsajátításában ahhoz, hogy különböző képességü gyerekekkel egymástól eltérő módon tudjon bánni

- Megismerje és megtanulja a hospitálások gyakorlata alapján a jól szervezett fegyelmet és rendet, ami a nyugodt munka biztosítéka

- Facilitálja a gyermek ,koncentrált” munkáját

A konduktor-tanító hallgató tevékenységének megfigyelési szempontjai voltak:

1. Hogyan biztosította a hallgató a családias, ,nyugodt légkört”?

2. Biztosította-e játékidőben a gyermek mozgásszükségletének kielégítését?

3. Milyen szokások alakítására fordították a legtöbb gondot?

4. Milyen volt a kapcsolat a gyerekekkel?

5. Mit tett a gyerekek szocializálódásának tanítása érdekében?

6. A gyermek által választott Montessori eszközök neve:

7. A kiválasztott eszközt választotta-e már? Hányszor? Miért?

8. Milyen segítséget kapott a játéktevékenység kivitelezéséhez?

9. Az eszköz kiválasztásában és alkalmazásában milyen volt az önállósága?

10. A gyermek szenzibilitásának megfigyelése.

12. Érvényesül-e a gyermeknél az elidőzés módszerének alkalmazása?

13. Érvényesül-e a pedagógiai provincia kialakítása?

14. Eljut-e a gyermek alkalmanként a felfedezés öröméhez?

15. Kommunikációs helyzetekben való részvétel.

A gyakorlat helye a Pető Intézet gyakorlóterületén a Villányi úti épületben volt, konduktív kisiskolás csoportban.

A foglalkozások tanórán kívüli tevékenység keretében valósultak meg. Részt vett a gyakorlatokon a csoportvezetö konduktor, a föiskola metodikusai, a konduktív gyerekcsoport megbízott konduktora és a hallgatók csoportja. A teremben úgy helyezkedtek el, hogy a foglalkozások menetében, a belső térbe ne avatkozzunk bele. A foglalkozást a felkészült hallgató és 
helyettese szervezte, irányította. Az egyéni konduktív célok megvalósításában a súlyosabb gyermek mellé facilitáló hallgatót tervezett és kért fel a foglalkozásvezető.

A gyakorlat során próbáltuk a lehető legtöbb elemét átvenni a Montessori által kidolgozott módszernek, a csendjátékot, az eszközöket, bemutatások szabályait, a háromlépcsős tanulási folyamat modelljét és természetesen az általa képviselt nevelési elveket és módszereket.

A foglalkozásokat mindig körben /szönyegen ülve/ beszélgetéssel kezdtük. A beszélgetés mindig kiterjedt az aktualitásokra /dátum, időjárás stb., melyeket a gyerekek naptáron, táblázaton be is jelöltek/ valamint azokra a kérdésekre, amelyek a gyereket érdekelték, foglalkoztatták. Ezután a foglalkozás vezetője egy aktuális témáról kezdeményezett kötetlen jellegü beszélgetést. Ez lehetett ünnep vagy akár hétvégi élmény stb. Különböző közösségi szabályokat alkottunk, melyeket folyamatosan bővítettünk azért, hogy a gyermekek megszokják, hogyan viselkedjenek a beszélgető körben, a foglalkozásokon. Ezeket szabálykönyvben piktogramokkal dokumentáltuk. Egyik ilyen jellegzetes „Montessori” szabályunk volt, hogy a körben nem kell jelentkeznie annak, aki mondani szeretne valamit, hanem egyszerüen a szemével jelez, ha valamit szeretne elmondani a többieknek. Ezt a szabályt a gyakorlatban meglehetősen nehéz volt kialakítani, hiszen a gyerekek ezt a másfél órát kivéve a hét többi napján jelentkezéssel válaszoltak, illetve kommunikáltak a csoportfoglalkozásokon.

A beszélgetést követte az ún. csendgyakorlat, mialatt a gyerekek megfogták egymás kezét, és eközben nyugodt, instrumentális zenét hallgattak. A csendgyakorlat alatt mindig körbeadtunk egyegy érdekes tárgyat, amely lehetőség szerint kapcsolódott a beszélgetéshez vagy a bemutató játékhoz. Ilyenkor megpróbáltunk egymásra hangolódni, figyelni a zenére, a társak rezdüléseit érezni. Egészen különleges élmény volt a gyerekekkel így a körben ülni. A csendgyakorlat azonban nemcsak az egymásra figyelést erősítette, hanem a feszültségeket, az indulatokat is levezette. Voltak olyan időszakok a gyerekek életében, amikor a gyermekek izgatottabbak, érzékenyebbek voltak az átlagosnál. Ennek oka lehetett, hogy hosszabb szünet után találkoztunk, vagy valami különleges esemény történt aznap velük. Ilyenkor nyugtalanabbá vált a csendjáték.

A csendgyakorlat után következett az új eszköz bemutatása. Az eszközre vonatkozó magyarázatot mindig igyekeztünk röviden elmondani, bemutattuk, eljátszottuk a 3 lépcsős leckét és azt, hogyan ellenörizhetik magukat a gyerekek. Ezt követte a szabad eszközválasztás folyamata, volt, aki a szőnyegen maradt az újeszközzel, vagy aki elindult a konduktív járásfeladatának megfelelően a polc felé eszközt választani. Az eszközről meg kell jegyezni, hogy azokkal megadott szabály szerint kellett játszani, amit a szabálykönyvben rögzítettünk. Ezeket az eszközöket viszonylag könnyen tudták a diszfunkciós gyerekek használni. Élményt nyújtott nekik a tevékenység, és sikerekhez juttatta őket.

A diszfunkciós gyermekeinknél a közlekedés nem volt egyszerü dolog, kinek-kinek megfelelö segédeszközre és segítségadásra volt szüksége, ezért a foglalkozás ezen részében mindenképp nevelői segítséget igényeltek. A járásmódokat, a segítségadás módját a konduktív programoknak megfelelően a foglalkozás vezetőjének kellett megtervezni és a szükséges eszközöket a gyerekek számára biztosítani. Az eszköz kiválasztáshoz a gyerekek szükségképpen szatyrot vihettek magukkal, ebbe pakolhatták a kiválasztott eszközt, amellyel a segédeszközükre vagy kezükre akasztva mehettek a tevékenységük helyszínére. Nem külön szőnyegekre ültek, mint ahogy azt a Montessori óvodában láthattuk, hanem asztalhoz, vagy szőnyegen hason fekve, nyújtott ülésben, esetleg törökülésben tevékenykedtek, ahogy ezt a gyermekek mozgásállapota indokolta. A tevékenység időtartama a közlekedési feladatok megvalósításának figyelembevételével kb. 20-25 percre volt tehető, egy-egy foglalkozáson. A szabad tevékenységet követően ugyanis a gyerekeknek az eszközöket vissza kellett vinni a polcra, oda, ahonnan elvették őket. A foglalkozás záró része az értékelés volt, a viselkedési szokásokra, illetve a konduktív feladatok megoldására terjedt ki.

A foglalkozás befejezése után a hallgatói csoportos elemzése, értékelése következett. A hallgatói csoport tagjainak a foglalkozás ideje alatt egyrészt a gyermekeket, másrészt a foglalkozást vezető hallgatótársukat kellett megfigyelni. A gyakorlat utáni elemzést a hallgató feladatának önelemzése követte. A gyermekek megfigyelését folyamatosan a Pedagógiai Naplókban rögzítették. 
A megfigyelés hatékonyságát biztosította, hogy a hallgatók minden alkalommal ugyanazt a gyermeket figyelték meg.

\section{Eredmények}

A tapasztalatok és a hallgatói megfigyelések igazolták, hogy a Montessori pedagógia elvei eredménnyel adaptálhatók, alkalmazhatók a konduktív pedagógiában. Ezt a ténymegállapítást mind az oktatók, mind pedig a képzésben részt vevő hallgatók is egyértelműen megerősítették.

Leginkább az életvitelhez és az érzékelés fejlesztéshez szükséges eszközöket készítettek a hallgatók. Néhány anyanyelvi, matematika és kozmikus eszköz is volt. A kozmikus hagyományosan a természetismeretet jelentette.

A kiscsoportos munkaszervezés optimális volt az egyéni megfigyelés szempontjából. Montessori elképzeléséhez hasonlóan a gyermekek tevékenységét fejlődésükben és folyamatos megfigyelés útján szerveztük meg. Tapasztalati összegzésre nyílt lehetőség. A program pozitív hatásai között meg kell említeni, hogy az állandó feszes tempójú napirendben a tanulás ilyen, másfajta megközelítése üdítően és inspirálón hatott a gyerekekre. Segítette a koncentrációt, a figyelem tartós, egy dologra való összpontosítását.

Nyitottabbá, nyugodtabbá váltak a gyerekek a Montessori foglalkozás után, spontán sikerültek nekik azok a dolgok, amelyek direkt, irányított törekvés után máskor nem. A siker titka talán az a látszólagos ellentmondás, hogy bár nagyobb szabadságot kaptak, mint egyéb alkalmakkor, mégis láthatóan fegyelmezettekké váltak, saját maguk munkáját kontrollálhatták.

Az eszközök önálló használatának segítségével a gyerekek a tevékenységen, tapasztaláson keresztül tanultak. Ugyanakkor a Montessori eszközök alkalmazásával lehetővé vált, hogy önálló felfedezéseket tegyenek, és így bővítsék amúgy szük tapasztalatszerzési lehetőségeiket. Mindezt saját spontán fejlődésük ütemében, saját képességbeli tudásuk alapján tették meg. Érdeklődésükre egészséges kíváncsiság volt jellemző, és az eszközök használatával azt tapasztalták meg, ami az eszköz megismerésének jártasság vagy készség szintjén jelentette. Helyes irányba terelte a gyermekek törekvéseit, mert itt nem egy kívülről „,rákényszerített” feladatról volt szó. Amíg nem sikerült helyesen megoldani a feladatot, addig önként és nagy odafigyeléssel dolgoztak rajta, hisz az még akkor sem kudarc volt, csak próbálkozás.

Az eredményeket bizonyította, hogy a hallgatók többsége a záró tanítását a Montessorifoglalkozások keretében valósította meg. Szakdolgozatokat írtak a témában. Tíz év távlatából tekintve a programra, egyértelmü hússzúra nyúló hatása, hiszen a vezetők részéröl képviselt támogató szakmai és lelki szemlélet eredménye, hogy a 2018-as tanévben is született Montessoriszakdolgozat. A programban részt vett és végzett konduktor hallgatók munkájában nyomon követhető volt a Montessori program elemeinek további alkalmazása. Sikerrel alkalmazták a tapasztalatokat külföldi munkájuk során (pl. Írországban), sőt felkutattak Montessori intézményeket is. Alternatív pedagógia iránti szemléletük, érzékenységük fejlődött, módszertani kultúrájuk gazdagodott. A hallgatók leginkább az óvodai foglalkozásokon alkalmazták.

\section{Korlátozások}

Az választott kísérleti formának (egycsoportos, önkontrollos kísérlet) a megbízhatósága nem pontos, mivel a független változó (a Montessori módszer) által okozott módosulás nagyságát csak a tapasztalati valószínűséggel lehetett egybevetni és emiatt a változás mértékét minősíteni nem lehetséges.

\section{Konklúziók}

A tapasztalatok és a hallgatói megfigyelések igazolták, hogy a Montessori pedagógia elvei eredménnyel adaptálhatók, alkalmazhatók a konduktív pedagógiában. Ezt a ténymegállapítást mind az oktatók, mind pedig a képzésben részt vevő hallgatók is egyértelmüen megerősítették. 


\section{Irodalom}

Bíróné Balog, V., Bordács, M., \& Németh, A. (1998). Maria Montessori pedagógiája. In Pukánszky, B. \& Zsolnai, A. (Ed.) Pedagógiák az ezredfordulón. Budapest: Eötvös Kiadó. 13-30.

Csíkos, Cs. (2012). Pedagógiai kísérletek kutatásmódszertana. Budapest. Gondolat Kiadó.

Falus, I. (1993). A pedagógiai kutatás metodológiai kérdései. In: Falus, I. (1993, szerk.): Bevezetés a pedagógiai kutatás módszereibe. Budapest: Kereban Kiadó.

Hári, M., Kozma, I., Horváth, J., \& Kökuti, M. (1999). A konduktív pedagógiai rendszer hatékony müködésének alapelvei és gyakorlata. Budapest: Nemzetközi Pető Intézet.

Horváth, D., Salga, J. (2005) Integrációs modellkísérlet a Pető Intézet óvodájában. Fejlesztö Pedagógia. 2015/2-3, 22-27.

Huber, A. \& Kaul, C. D. (1993). Montessori workshop. Alapelvek, szemlélet. Bécsi Pedagógiai Akadémia, Budapesti Montessori Társaság.

Kim, R. (1998). A belső motivációt befolyásoló tényezők és megjelenésük a Montessoripedagógiában. Új Pedagógiai Szemle, 1998/3. Letöltés: 2018. április 11., Web: http://epa.oszk.hu/00000/00035/00014/1998-03-ta-Kim-Belso.html

Pukánszky, B. \& Németh, A. (1996). Neveléstörténet. Budapest: Nemzeti Tankönyvkiadó. Letöltés ideje: 2018.02.03. Web: http://mek.oszk.hu/01800/01893/html/

Mészáros, I., Pukánszky, B. \& Németh, A. (2003). Neveléstörténet. Szöveggyüjtemény. Budapest: Osiris Kiadó. Letöltés 2018.04.13. Web:https://www.tankonyvtar.hu/hu/tartalom/tamop425/2011_0001_520_nevelestortenet/ch02 s13.html

Sung-Hui-Kim (2008). Kreativitätsförderung und Montessori-Pädagogik: Untersuchungen bei Kindern im Vorschulalter. LIT; 1. 